\title{
STALIN, THE GREAT PURGE, AND RUSSIAN HISTORY: A NEW LOOK AT THE NEW CLASS'
}

by

MARSHALL SHATZ

Paper No. 305

1984 


\section{STALIN, THE GREAT PURGE, AND RUSSIAN HISTORY: A NEW LOOK AT THE 'NEW CLASS'}

by

MARSHALL SHATZ

Paper №. 305

1984

Marshall S. Shatz received his B.A. from Harvard College and his M.A., Certificate of the Russian Institute, and Ph.D. from Columbia University. He edited The Essential Works of Anarchism (New York: Bantam Books, 1971; Quadrangle Books, 1972) and is the author of Soviet Dissent in Historical Perspective (Cambridge and New York: Cambridge University Press, 1980). He is Professor of History, University of Massachusetts at Boston. 
STALIN; THE GREAT PURGE; AND RUSSIAN HISTORY:

A NEW LOOK AT THE 'NEW CLASS'

Though nearly fifty years in the past; Stalin's Great Purge of the 1930s still looms as one of the most enigmatic events of the twentieth century. Whether we think of the Great Purge as a more or less continuous process fram the assassination of Kirov in 1934 to Ezhov's replacement by Beria as head of the secret police at the end of 1938; or limit it to the Ezhovshchina of 1937 and 1938; when the terror reached its peak; the sheer magnitude of the operation is astounding. The number of arrests; deportations; imprisonments; and lives lost in these years is impossible to measure; and attempts to do so have varied wildly. Even the lowest estimates; however; are staggering. ${ }^{1}$ It is not merely the size of the Great Purge that makes it such a historical puzzle; however; but the fact that it took place in peacetime; in a society publicly and officially comitted to rational values and the humanistic ideals of Marxism and the Russian revolutionary tradition. In its controlled and organized character the Great Purge seems comparable not to the primitive upheavals of "underdeveloped" countries in the second half of the twentieth century, nor to the spontaneous bloodletting Russia itself experienced during the Civil War; but rather to the Nazi destruction of European Jewry in the Holocaust. Like the Holocaust; it is the seemingly atavistic nature of the Great Purge; as much as its actual consequences; that has presented such a challenge to scholars seeking to explain the events of the Stalin period.

The resources available for meeting that challenge have increased considerably in recent years. First; both the official "de-Stalinization" campaign begun by Khrushchev and the unofficial re-examination of the Stalin era by soviet dissidents have generated a wealth of new material and 
information. With the appearance of such documents as Khrushchev's "secret speech" to the Twentieth Party Congress in 1956; a plethora of memoirs and personal testimonies of the Great Purge; and literary works which distill the atmosphere and experiences of the time, our knowledge of what occurred in the thirties has vastly increased; though significant gaps remain and many of the new sources that have come to light are less than fully reliable. 2 Just as important, perhaps; as the availability of new sources is the reinterpretation of old ones. The passage of time itself is beginning to alter our view of the Stalin period as the Great Purge becomes part of our historical consciousness rather than of our recent experience. Without "nomalizing" the Great Purge or denying its unprecedented character and still unexplained origins; we are now in a position to view it in a broader historical perspective than was possible earlier; perceiving more clearly its place in the larger patterns of Russian and world history. As a result; new light has been shed on materials long available but insufficiently appreciated or understood. 3

Thus the subject of the Stalin period, and particularly the Great Purge, has been undergoing a significant reinterpretation in recent scholarly works. The nature and implications of this change form the subject of this essay. Its purpose is threefold: to classify and evaluate the main trends and interpretations that have hitherto marked the historiography of the Stalin era; to identify the new direction in which recent studies of the period have been moving; and to suggest some of the broader historical insights that might be drawn fram this new orientation. The essay does not attempt to provide an exhaustive historiographical or bibliographical survey of the subject. The works selected for citation and discussion are those which; in the author's opinion, best represent the most serious and influential interpretations of the Stalin era. 
The Stalin period of Russian history places the scholar in an unusual predicament. It is bad enough that Stalin's Russia, in Churchill's incomparable phrase, is "a riddle wrapped in a mystery inside an enigma." Even worse; in regard to the Great Purge; which must occupy a central place in any study of the Stalin period, the enigma itself remains under lock and key in the archives of the secret police. The direct sources are firmly closed to Western scholars (and presumably to Soviet scholars as well), while the public record - newspapers, speeches, official documents - is notoriously unreliable. It was intended to propagandize rather than to inform; to conceal rather than to reveal; or; at best; to transmit coded information to the initiated. Such sources may well prove useful in various ways, but they cannot serve as a solid foundation for a study of the Great Purge.4 As a result, scholars have had to be unusually inventive in extracting information and clues fram a variety of more indirect sources. Here, we shift fram Churchill's metaphor to the old story of the three blind men trying to describe an elephant by touch: each historian's explanation of the Great Purge depends on his interpretation of the part of the record he manages to put his hands on; the bulk of the phenamenon remaining out of reach. To a considerable degree the documentary record; or absence thereof; has shaped the historiographical record; as scholars have constructed a variety of interpretive frameworks to hold such information as they have been able to glean.

Of the major approaches to the subject; perhaps the most inventive, by its very nature; has been the psychological; the attempt to come to grips with Stalinism by focusing on the personality of its perpetrator. In its most primitive form; this approach explains - or, more accurately, explains away 
- Stalin's major actions as simply the product of a warped psyche. The outstanding example of this genre is Khrushchev's "secret speech" of 1956. By painting a picture of Stalin as "a very distrustful man; sickly suspicious," 5 and attributing his misdeeds to these character defects (and the character defects of a few other evil-doers such as Beria); Khrushchev sought to deflect any attempt to trace the roots of Stalinism to defects in the Party, the ideology; or other Soviet institutions. He thus shielded from criticism the sources of his own authority; neatly avoiding the kind of socio-economic analysis that might have been expected from the keeper of the Marxist-Leninist flame. Each in its own way; Svetlana Allilueva's image (in her first book) of a Stalin "deceived" by Beria; so reminiscent of popular myths about the tsars, and Antonov-Ovseenko's depiction of Stalin as gangster, fall into this reductionist category. 6

On a more sophisticated level are the several examples of psychobiography; the effort to apply formal psychological (including psychoanalytic) theory to the person of Stalin. ${ }^{7}$ Several studies have employed the concept of paranoia in trying to formulate a deeper and more revealing psychological profile. 8 The most ambitious psychobiographical study to date is Robert Tucker's Stalin as Revolutionary; the first volume of a projected series. ${ }^{9}$ All of these works suffer both from the specific difficulties of studying Stalin and the inherent weaknesses of psychobiography itself. The bibliographical obstacle proves virtually insurmountable: the sources on Stalin's childhood and adolescence; the formative years crucial to any psychoanalytic investigation; are so scanty and unreliable that very little can be inferred fram them. Thus Tucker's book; a well-informed and historically sensitive Eriksonian treatment; is; at best; highly speculative as a psychological study. Even for Stalin's later years there is a signal 
lack of the kind of personal documentation a psychobiography requires: memoirs; personal letters; "table-talk." The biographer is therefore forced to rely on illuminating but distinctly second-hand accounts such as Svetlana Allilueva's two books and Milovan Djilas' description of his encounters with Stalin in his last years. 10 To varying degrees; psychobiographical studies of Stalin also reflect the lack of agreement within psychological theory itself on the sources and dynamics of personality formation; ignore the cultural problem of applying any such theory to an individual from a Georgian peasant background; and illustrate the difficulties of applying psychoanalytic concepts and methods to a literary record rather than a live patient. 11 At best, the attempt to pursue a systematic psychological analysis of Stalin asks important questions that may be inherently unanswerable. At worst; it risks accounting for Stalin's public policies and political decisions in the simplistic terms of personal pathology.

The most widespread and influential approach to the Stalin period in Western historiography; at least until recent years, utilized the concept of totalitarianism. In this theory the salient features of Stalinism, including the element of terror; while significantly affected by the particular personality of the dictator; are regarded as integral elements of the political system he headed. Originating in application to Fascist Italy and Nazi Germany; this "model" was subsequently extended and refined to include Stalin's Russia. It regards totalitarian regimes, characterized by mass political control based on both manipulation and terror, as a new and unprecedented political phenomenon of the twentieth century. The most elaborate application of the totalitarian model to the soviet Union is Friedrich and Brzezinski's Totalitarian Dictatorship and-Autocracy, which delineates a syndrome of six features characteristic of Nazi Germany; Fascist 
Italy; and Stalin's Russia. The same outlook permeates Merle Fainsod's classic How-Rassia-Is Ruled and Smolensk under Soviet Rule. ${ }^{12}$ The most systematic application of the totalitarian model to the specific subject of the Great Purge is Zbigniew Brzezinski's The Permanent Purge. This work views the purge as an inherent feature of the totalitarian system of government, a characteristic instrument of totalitarian rule; though one that may vary in nature and intensity over time. Hence the Great Purge differed only in degree, not in kind; from other Party purges before and after it. ${ }^{13}$

The totalitarian model has fallen out of favor since about the 1960s. On the one hand; there has been a growing awareness and documentation of how diverse and competitive political life within the Soviet system can be, with a broad range of policy opinions and group interests striving for influence and requiring conciliation. This realization has raised at least the possibility that political life under Stalin also was less rigidly controlled than previously thought. 14 To be sure, not all students of Soviet politics - much less of the Stalin era - are prepared to accept the notion that Soviet political life is characterized by "pluralism" in any meaningful sense, or that concepts of political analysis drawn from Western experience are fully applicable to the Soviet case. ${ }^{15}$ At least some elements of the totalitarian concept may continue to be useful in comprehending the methods and aspirations of the Soviet political system. Nevertheless; our image of the Soviet Union, even under Stalin; has grown increasingly complex and remote from the fullblown image of monolithic totalitarianism that prevailed in an earlier era. At the same time; the totalitarian model has been undermined by the sheer passage of time. While the fundamental political; social; and economic structure Stalin created has remained intact; the all-pervasive terror once thought essential for maintaining that structure has virtually ceased, and 
Soviet institutional life has been largely stabilized. Such an evolution is difficult to account for in terms of the totalitarian model. It suggests either that the differences between the Soviet system, on the one hand, and German Nazism and Italian Fascism; on the other; were more fundamental than previously thought; in which case little remains of the Friedrich-Brzezinski model; or that some of the salient features of Stalinism were temporary, historically conditioned aspects of Soviet development rather than essential characteristics of the system. In either case, the interpretation of Stalinism as a Russian version of twentieth-century totalitarianism loses much of its usefulness.

A third, considerably more varied, approach to the Stalin period is the ideological, which regards the adoption, or distortion, of Marxism as the key to an understanding of Stalinism. Broadly speaking, this approach is shared both by those opposed to Marxism in any fonm and those opposed to the particular version of it represented by Stalin. Of the first group; some have located the roots of Stalinism in the displacement of traditional, authentic Russian moral values by the alien outlook of Marxism; with its destructive materialism, rationalism; and moral relativism. Alexander Solzhenitsyn is the leading representative of this viewpoint, and it informs both his fictional works on the Stalin period and his massive Gulag Archipelago. It is a position particularly associated with a commitment to religious faith as the source of the true moral values so shockingly violated under stalin in the name of the official ideology, a commitment expressed most clearly by Solzhenitsyn and his associates in the volume of essays entitled From Under the Rubble. 16 It may also be found in a more general and secular form, as in Nedezhda Mandel'shtam's harrowing account of the ordeal she and her husband underwent at Stalin's hands: here, the author traces Stalinism ultimately back 
to the jettisoning of the Judeo-Christian moral tradition; which lay at the foundation of her husband's poetry; by a light-minded intelligentsia in the name of the "progressive forces of history."17

Others have located the sources of Stalinism in Ienin's particular use, or misuse; of Marxism: with his dictatorial proclivities and disciplined Party claiming the right to rule on the basis of a higher wisdom; it was Lenin who gave Stalin the necessary tools for building his regime. While recognizing that little direct precedent can be found in Lenin's own years in power for such actions as collectivization or the Great Purge; this interpretation sees an underlying political continuity and consistency between Leninism and Stalinism in their common dictatorial nature. Thus the roots of Stalinism go back to the October seizure of power from the fledgling democracy of the Provisional Government; and the establishment of one-party rule by the Bolsheviks. This has been the view frequently taken by Western liberal scholars. 18

By contrast, the one proposition that unites virtually all those sympathetic to Marxism and to the socialist aspirations of the Russian Revolution is that Stalinism was not the legitimate heir of Ieninism but an unlawful usurper; just what the rightful successor was; and at what point the usurpation occurred; however, remain matters of contention. In Roy Medvedev's Let History Judge; which ranks with Robert Conquest's The Great Terror and Solzhenitsyn's Gulag Archipelago among the most extensive studies of the period of the Great Purge; the road to Stalinism begins only with the death of Lenin in 1924; to Medvedev; this is the great turning-point of Soviet history. He acknowledges no continuity at all between the political methods of Lenin and Stalin; even to the extent of justifying on the grounds of historical necessity Lenin's establishment of one-party rule and restrictions 
on internal Party dissent in the early twenties - justifications which he does not find applicable to similar actions taken by Stalin. 19

The best-known; most prolific; and; at least until recently; most influential school of thought which sees Stalinism as a degeneration of Soviet socialism is the one emanating from Trotsky's analysis. Not surprisingly, Trotsky and his adherents, explicitly or implictly, date the degeneration from Stalin's defeat of Trotsky and the Left Opposition in the late twenties. Unwilling to repudiate the Bolshevik seizure of power or the foundations of the Soviet system which he himself had done so much to construct, but unable to accept Stalin's stewardship of that system, Trotsky formulated his theory of Stalinism as a "degenerated workers' state." In The Revolution Betrayed; written on the eve of the Great Purge in 1936 and constituting his major exposition of this theory, he argued that the authentically socialist and proletarian Russian Revolution had somehow produced not the rule of the working class but the seizure of power by a "bureaucracy" spear-headed by Stalin - though precisely where that bureaucracy came from and what its power rested on remained unclear. Even after the Great Purge; in the biography of Stalin that he was working on at the time of his assassination in 1940, he still presented Stalin as an utter mediocrity and opportunist, a faceless creature of the bureaucracy whose interests he represented. Trotsky's commitment to the Revolution and Bolshevism; his search for a Marxist explanation of Stalin's rule; and his understandable desire to denigrate Stalin, generated a campelling interpretation of Stalinism; but one camposed of fundamentally contradictory ingredients. 20

More recent scholarship on the Stalin period has placed greater emphasis on Bukharin, and the program of the Right Opposition; than on Trotsky as an alternative to Stalinism. This position has been enhanced by increased 
skepticism regarding the economic efficacy of Stalin's Five-Year Plans; particularly in agriculture. 21 From this standpoint; of course; the defeat of the Right rather than the Left; and the elimination of "Bukharinism" as an econamic and political alternative; represents the irrevocable step toward Stalinism and its works.

Finally; there is Khrushchev's position; which takes 1934; and the assassination of Kirov; with all its attendant consequences; as the startingpoint of Stalin's "excesses." As the heir to the political and economic system Stalin molded; Khrushchev had no incentive to raise fundamental doubts about the Party structure and methods of rule that ensued from the political struggles of the late twenties; or about Stalin's collectivization and industrialization programs. In his "secret speech" he confined himself to same mild reservations about the way it was all carried out. He carefully reserved his repudiation of Stalinism for events after 1934 - the Great Purge; the deportation of national minorities; aspects of the conduct of the war - when; of course; the foundations of the current soviet system were already in place.

In the company of those who have scrutinized Stalin from a point of view sympathetic to the Russian Revolution and Marxism; Isaac Deutscher today stands virtually alone in his ultimately positive appraisal. His classic biography of Stalin; while drawing on Trotsky's analysis and in no way concealing Stalin's less savory deeds; concludes that the Stalin period was a harsh; but historically necessary phase in the construction of the world's first socialist society: "What appears to be established is that Stalin belongs to the breed of the great revolutionary despots; to which Cramwell; Robespierre; and Napoleon belonged....Stalin undertook; to quote a famous saying; to drive barbarism out of Russia by barbarous means... Stalin has been 
both the leader and the exploiter of a tragic; self-contradictory but creative revolution."22 At the other end of this spectrum is Jean Ellenstein; a French Communist who seeks to dissociate European socialism almost entirely from the historical form it assumed in the Soviet Union. To Ellenstein, the "Stalin phenomenon" had considerably more to do with Russian backwardness and despotism than with the inherent nature of socialism; European Canmunism, therefore, arising in an advanced industrial society with deep-rooted democratic traditions; will assuredly prove much more civilized. 23

A fourth approach to the question of Stalinism, perhaps the broadest and most general one; views it in terms of one or another non-Marxist form of modernization theory; an example of the phenomenon of the industrialization of backward agrarian societies. It can hardly be denied that such a transition was occurring under Stalin, although the precise degree of Russia's "backwardness" after half a century of tsarist industrialization effort is at least debatable. One problem with this approach, however; is that Stalin's methods of rapid industrialization have not been repeated in other "underdeveloped" nations in any recognizable form; it is the peculiarities of the Soviet experience under Stalin that seem to stand out in any comparative perspective; and efforts to fit that experience into a broader pattern or model of development have proved unconvincing. 24 Another difficulty is that the relationship of same of Stalinism's most visible features - e.g.. collectivization; the Great Purge; cultural conservatism - to the functional needs of large-scale industrialization is either dubious or downright mystifying. 25 Theodore Von Laue, emphasizing the external pressures on Russia to industrialize in order to preserve her sovereignty in a competitive world, offers a variation on the modernization theme cast in a mold of historical determinism. 26 Neither this argument nor Deutscher's Hegelian/Marxist concept 
of historical necessity adequately explains why Russian industrialization took the particular pathways by which it proceeded under stalin.

Each of the interpretations outlined above has made its contribution, and each has shed light on; or at least called attention to; some important aspect of Stalinism. None of them has proved fully satisfactory or enjoyed a very long scholarly life; however, and the reasons appear to go beyond the limitations specific to each one. If we re-examine these various approaches and "models" we find a general characteristic underlying almost all of them; with the exception of the developmental model, most studies of Stalinism have perceived it as an aberration of some sort, an abnormal development; a deviation fram a norm. Whether the norm be psychological (Stalin as a deviant personality); political (totalitarianism as an aberrant political system), or ideological (Stalinism as a violation of liberal values, religio-moral tradition, or true Marxism); Stalin's actions and policies have been regarded as a falling away fram a standard; the task at hand; therefore; has been to measure the distance fallen and describe the evil consequences. ( $I$ am not referring, of course, to the notion that Russia itself is an aberration and Stalinism a mere continuation of traditional Russian - if not Tatar! barbarism.) Even aside fran the value judgments implicit in such an enterprise; it is difficult to explain the impressive longevity of an aberration; the ability of Stalin to acquire and maintain his power for some twenty-five years and of the Stalinist system to endure even in the absence of terror, "true" Marxism or Leninism; or Stalin himself. Paradoxically, the one exception to this historiographical practice, the application of modernization theory; suffers from the opposite defect: in effect; it has tried to fit an exceptional; or unique; national experience into a model which will not accormodate it. 
All of the above approaches share a second broad characteristic which helps to account for the first one. They view the Stalin era in terms of a universal pattern or experience; of which the Soviet Union under Stalin is but one instance. Whether it be totalitarianism; Marxism; third-world development; or even psychoanalytic theory; Stalin and his policies are taken as a case study of some more general phenomenon. In large part; this stems from the fact that until fairly recently most scholars of the Stalin period have employed the methods and approaches of the social sciences: by and large; they have been political scientists; sociologists; econamists; Marxists of various stripes; rather than specialists in Russian history and culture. It is not that the social sciences have usurped Clio's turf; but rather that the ground has been abandoned to them: historians have shied away from such a recent and politically charged subject; and students of Russian culture have found little to attract them in the thirties and forties. 27

Consequently; the tendency has been to treat the subject from a perspective which plucks the Stalin era out of its Russian historical and cultural context and places it in the context of a larger model of social; political; or economic development. From the point of view of most such models; derived as they are largely fram Western experience; Stalinism does indeed look like an abnormality. Not that these various perspectives are entirely incorrect; or their practitioners ignorant of things Russian - on the contrary; they have provided us with many specific insights and a foundation for further investigation. But they have failed; on the whole; to explain the rise and perpetuation of Stalinism.

It is only in recent years that Russianists; that is; historians; literature specialists; and other scholars whose basic starting-point is Russian history and culture, have turned their attention to a systematic 
examination of the Stalin era. Putting to use both the new material available and the broader historical perspective now possible; they have begun to reorient our thinking on the subject. What this recent work is uncovering is the extent to which stalinism fits into the broad pattern of Russian historical development and forms an integral part of it. To be sure, much about Stalinism remains; and probably will remain, irrational and "aberrant," but the Stalin period as a whole is becoming more comprehensible as a phase of Russian history. The next section of this paper summarizes the principal direction of recent work on Stalinism and some of the conclusions that may be drawn from it.

II

The most significant aspect of recent scholarship on Stalin is its emphasis on the beneficiaries of Stalinism and of the Great Purge itself, rather than just its victims. Nor were these beneficiaries limited to the "provocateurs" and "conscienceless careerists" on whom Khrushchev blamed the mass terror of the Ezhovshchina. 28 Stalin's policies; from the First FiveYear Plan to the Great Purge, were accompanied by the rise of a broad new Soviet elite which helped to consolidate Stalin's power and the system he created in those years. In itself; the emergence of this elite is not a new discovery; references to the "new class" of Soviet rulers; the term popularized by Milovan Djilas; can be found in mach of the literature cited above. 29 It is only in more recent scholarship; however; that the character of this new elite has been clearly delineated and the full importance of its promotion disclosed. Rather than the rise of a "new class," a concept whose misleading implications will be discussed later in this essay; we may more accurately characterize the Stalin period; with the Great Purge as its centerpiece, as the triumph of plebeian Russia. 
To use a kind of sociological shorthand; the members of this new elite were essentially "the Khrushchevs." In Nikita Khrushchev we have an outstanding representative of the new elite; and also; in his memoirs, an invaluable expression of the outlook and mentality it brought with it into its new positions of authority. Like so much of the Russian "proletariat" in the early twentieth century; Khrushchev was a peasant-worker. Born in a peasant village, he went to work early on as a metal-fitter at a coal mine in the Donbass and never looked back to the countryside. Here was a man whose identification with urban-industrial values had the whole-heartedness of a recent convert; but who had been formed in the village and still bore many of the marks of peasant culture. A major key to the subsequent behavior of "the Khrushchevs" lies in the interaction between the aspirations of such individuals within the new industrial society Stalin was constructing and their deep-rooted peasant heritage. 30

The first step in the rise of the Khrushchevs was the mass recruitment of workers and peasants into higher technical education; and their pramotion into managerial and administrative positions during the First Five-Year Plan. The work of Sheila Fitzpatrick and Kendall Bailes; in particular; has charted this social development. It was signalled by the Shakhty Affair, a show trial in the spring of 1928 of mining engineers accused of sabotage. This was the first step in an attack on the old technical intelligentsia; or "bourgeois specialists;" on whose industrial skills the regime had hitherto been dependent. The attack on engineering personnel culminated in the Industrial Party trial of 1930; while "specialist-baiting" in various forms constituted a significant element of the "cultural revolution" which accompanied the First Five-Year Plan. 31 The positive side of this process was an effort to create a new Soviet intelligentsia drawn from "socially reliable" elements of the 
population. This effort took the form of a massive and deliberate campaign to draw new people of worker and peasant background into technical and engineering education; including the use of such devices as social class quotas in educational institutions. The leading proponent of this drive; with remarkable consistency throughout the thirties; was Stalin. Although precise figures on social origin are difficult to determine; Sheila Fitzpatrick has estimated that some one-hundred thousand adult workers and worker-Cammunists were sent to higher technical schools during the First Five-Year Plan; and this was only part of the educational mobility of the period. 32

Individual beneficiaries can be found in the memoir literature. Khrushchev himself was a prime product of the campaign: at the age of 35 he entered the Stalin Industrial Academy in Moscow to study metallurgy from 1929 to 1932. Another example was the future General Petro Grigorenko; somewhat younger than Khrushchev but also born and brought up in a peasant village. In 1928 Grigorenko recruited for; and himself attended; a rabfak; a school to prepare young workers for higher education -- "the system's goal was the creation of a proletarian intelligentsia" - and at the age of 22 was sent to the Khar'kov Technical Institute to study construction engineering. 33

The rise of the Khrushchevs into positions of responsibility within the Soviet system in subsequent years; and the outlook and values they brought with them; help to explain a great deal about the contours of Stalinism. Although the Khrushchevs were not yet in a position to be directly responsible for the collectivization of agriculture; 34 Stalin must have found in them a firm source of support for it. Certainly the campaign against the traditional structure of peasant agriculture paralleled; and perhaps even validated; their personal rejection of their peasant heritage. Collectivization; after all; was not just the destruction of private landholding but a frontal assault on 
the traditional way of life of the peasantry. Having recently emancipated themselves from peasant tradition, sometimes at considerable psychological cost, they could find in the regime's attack on the countryside in the name of progress and modernity a confirmation of the rightness of their choice. As Grigorenko puts it in explaining his decision to leave the village and attend a technical school; "I felt I must go and build industry so that I could attack backward agriculture."35 That collectivization had at least the tacit approval of some of the most energetic and ambitious men of peasant background in the country may help to explain why it ultimately prevailed. 36

Given the background and ambitions of these rising plebeians; it is not surprising that in the Party power struggles of the late twenties they felt a strong sense of affinity for Stalin (and vice versa). From their point of view he did not loam as the crude; cruel intriguer that his rivals for power and their supporters depicted, but a practical, tough-minded, down-to-earth leader who knew how to get things done. The negative picture Khrushchev paints in his 1956 speech (which may well apply to the older Stalin) should be set against the admiration he and his young colleagues felt for the Stalin of the late twenties and early thirties, and for his supporters such as Kaganovich; because; in Khrushchev's phrase, they really made the chips fly when they chopped down the forest. 37 Moreover; Stalin's Marxism; crude and formulaic though it may have seemed to the better-educated Party members, sanctioned precisely the objectives that most appealed to the plebeian members: modernization of the country in the concrete, measurable terms of economic progress and national power. 38 As non-property owners they could find considerable attractiveness in the collective aspect of Marxism even as the Party served them as an instrument of upward mobility in much the same way as the Georgian Orthodox Church had done in Stalin's boyhood. Uninterested 
either in philosophical niceties or abstract visions of human liberation; they could readily accept an ideology reduced to economic and military development under the guidance of the Communist Party. On the whole neither conscienceless careerists nor faceless bureaucrats (though they could eventually become one or the other); they found in this prospect a satisfactory realization of both their ideals and their ambitions.

It is in the cultural realm that the rise of the Khrushchevs during the Stalin period is most vividly reflected. "Stalinist" culture of the 1930s and 1940s, whatever its value in absolute terms; reflected like a mirror the cultural level; tastes; and aspirations of the new elite. The conservatism of that culture; for example the peculiarly old-fashioned zest for fringed lampshades and overstuffed furniture, not to mention traditionalistic family and educational policies; is an aspect of the Soviet industrialization process that has long baffled theorists of modernization, whether Marxist or nonMarxist. But those archaic tastes in creature-comforts are precisely what might be expected of upwardly-mobile peasant-workers with limited cultural experience; their image of the good life remained; figuratively speaking, the scenes of bourgeois felicity glimpsed through the windows of the factoryowner's house in their youth; and it is not surprising that they would attempt to replicate it when they had the means to do so. The reversion of "socialist realism" to representational modes in art and literature; severing the ties that had previously existed between Russian avant-garde art and the Revolution, may have had practical value for mass propaganda purposes. At the same time, however, traditional representational forms were much better suited to the needs of the new ruling elite than abstract modernist forms: they 
conformed to the personal taste of the new commissars; and at the same time they made it much easier for men of limited education to censor and control the arts. 39

Even more specifically, recent re-examinations of the Soviet novel have brought out the extent to which the rise of the new elite is reflected in the very content of Stalinist literature as well as in its style and form. Katerina Clark has found that fram the First Five-Year Plan to the postwar period, the history of the officially approved novel in effect traces the life-cycle of the "new men" as they rise within the ranks of the system and mature. The novel of the First Five-Year Plan and the "cultural revolution," a period with a youthful, anti-elitist, proletarianizing thrust, glorified the "little man" and eschewed heroes. Such novels both reflected and provided ideological sanction for the rise of the plebeians. By the end of the First Five-Year Plan - by which time yesterday's "little men" were moving into positions of influence and responsibility-the novel begins to focus on a hero figure, the dynamic Party leader who carries out the dramatic exploits of the thirties. Finally, youthful heroics over, elements of materialistic complacency and self-gratification mark the postwar novel: hence the orange lampshades and scalloped doilies Vera Dunham finds as recurrent emblems of material well-being in forties novels, and the antique crystal that covers the table at the prosecutor's dinner-party in Solzhenitsyn's First Circle, which has a postwar setting. 40 clark points out a particularly revealing aspect of the novel's - and the Soviet Union's - evolution fram the 1930s to the 1940s. She found that the hero of the postwar novel tends to be older and more established than the typical hero of the thirties novel: he is now 35-40 years old, and instead of a young initiate into the Party he is an executive making his way into the upper reaches of the hierarchy. 41 To be sure, the 
whole of Soviet society was changing and settling down in these decades. But it is hard to escape the thought that for all it may tell us about soviet society in general; the Stalinist novel was a kind of biographical selfprojection, or even self-celebration; of the country's up-and-coming new elite.

If the attack on the "bourgeois specialists" and the mass educational enrollment of men of plebeian origins during the "cultural revolution" and the First Five-Year Plan marked the start of the new elite's rise; the Great Purge marked its culmination. The Ezhovshchina; with its decimation of the Soviet Establishment - Party secretaries; Old Bolsheviks; the professional and managerial ranks of Soviet society - enabled the new men to complete their rise and consolidate their position. In 1938, Stalin would speak of "a new, Soviet; people's intelligentsia," which Zhdanov identified as "yesterday's workers and peasants and sons of workers and peasants promoted to command positions." 42

The exact relationship of the Great Purge to the rise of the new elite is not entirely clear. Did it all represent a carefully thought-out plan on Stalin's part - a question which assumes that from 1928 he had the power, as well as the foresight; to carry out such a project? Did the promotion of an ideologically and politically more congenial elite, rather than leading by design to the Great Purge; merely create an opportunity for it, enabling Stalin as circumstances permitted to dispense with the services of those he had always distrusted as too independent-minded or rooted in the pre-Soviet past? ${ }^{43}$ Or; as J. Arch Getty has argued; was the rapid entrenchment of the new elite in the wake of the Ezhovshchina simply a coincidence, a social change that would have occurred eventually but was speeded up by a political event that had other causes? ${ }^{44}$ The redirection of attention to the 
significance of the new elite has led scholars to larger questions concerning the nature of the Soviet system in the Stalin period and Stalin's role within it; questions that need to be asked but can have no easy or immediate resolution. What seems increasingly clear; however; is that a very significant social development underlay the dramatic events of the decade from 1928 to 1938: the creation and rapid promotion of a new political and managerial elite and its displacement of the Soviet Establishment that had entrenched itself in the post-revolutionary years. The rise of this new elite -- sometimes called the "Brezhnev generation;" for Leonid Brezhnev was one of its members; 45 or "the class of '38" - cannot explain every facet of the Great Purge; and may or may not have been one of its major motivations. Nevertheless; it may well have been its most lasting consequence; requiring an "agonizing reappraisal" of the role of Stalinism in Russian history.

To identify the emergence of a new elite under Stalin has proved easier than to assess the nature and significance of the change that took place. Most frequently the new elite has been labelled "the new class;" a term that has came to designate the new ruling stratum that consolidated its power and privileges in the thirties and continues to daminate Soviet life today. It may be found both in older works representing the interpretations discussed in the first part of this essay; and in the more recent studies which have placed greater emphasis on the social change described in Part II.46 As an ironic metaphor for the re-emergence of privilege in a purportedly classless society; the term is harmless enough. As a historical or sociological designation; however; it risks serious distortion of what Stalinism actually signified; for it is; so to speak; a Marxist concept that is being used to describe a nonMarxist phenamenon. 
Although the widespread use of the term "new class" derives fram Milovan Djilas' popularization of it; the source of the concept; and Djilas' own inspiration; was Trotsky's notion of the "Soviet Thermidor;" the bureaucratic degeneration of the Revolution at the hands of the Stalinists. Trotsky himself; however; in The Revolution Betrayed and elsewhere; consistently repudiated the suggestion that the Stalinists constituted a new ruling class; on the grounds that they had effected no significant change in econamic ownership. The means of production remained nationalized; and there had been no reversion to capitalism. The bureaucracy represented not an econamic class but a ruling stratum; or caste; which had parasitically battened on the socialized economy as a consequence of Russia's backwardness. Trotsky said little about the precise social origins of these "bureaucrats;" hinting vaguely at the bourgeois or petty-bourgeois roots and mentality of at least some of them. 47

Ironically; it was some of Trotsky's followers; or former followers; who in the last year or so of his life began to use his analysis to develop a full-fledged "new class" theory which Trotsky himself had rejected. They argued; as Djilas was later to do; that the Cammunist Party; through its political domination; controlled the economy; enjoyed its profits; and perpetuated its own economic privileges; it had therefore replaced the capitalists as "owners" of the means of production and in a real sense formed a new ruling class. This theory effectively cut the Gordian knot which Trotsky had been unable to unravel: it applied the Marxist class analysis to the Soviet situation more consistently than Trotsky had done; while leading its practitioners precisely to the repudiation of the October Revolution and the Soviet Union which Trotsky had sought to avoid.48 And yet; it is difficult not to agree with Trotsky in rejecting the assertion that the Soviet 
rulers under stalin truly constituted a "class" in the Marxist sense. "The bureaucracy;" he pointed out; "has neither stocks nor bonds. It is recruited; supplemented and renewed in the manner of an administrative hierarchy; independently of any special property relations of its own. The individual bureaucrat cannot transmit to his heirs his rights in the exploitation of the state apparatus. The bureaucracy enjoys its privileges under the form of an abuse of power."49 However strong the analogy may be; there is a considerable difference between political control and economic ownership; between economic privilege and the inheritance of property; and therefore between the Soviet Communist Party and what Marx seems to have meant by the concept of class. When used in this case; the term "class" becames either a mere epithet or a concept so broad as to lose much of its analytical value. Although the phrase "new class" (like the term "totalitarianism") is by now too convenient and too deeply rooted in the literature to be done away with; we should at least be aware of just what it does; and does not; signify in the soviet context.

In the socialized economy of the Soviet Union; the socio-economic difference between the new people who were on the rise in the thirties and those they replaced; most visibly and dramatically as a result of the Ezhovshchina; was not very great. On the whole; the newcomers probably did come from a background farther down the economic scale than much of the old elite; but even in regard to those of peasant origin; once they had left the ranks of the land-owning peasantry there was little to distinguish them from the entrenched Party officials and managers; as far as property-ownership and wealth were concerned. The real gulf between them was cultural and educational. In culture and style the new men felt themselves to be very different from the educated stratum; with its strong links to prerevolutionary culture; that dominated the post-revolutionary Establishment. 
The former were people with only a rudimentary; or recently acquired education; no foreign travel or exposure to other cultures; and little experience of the humanistic niceties of the old educated elite. These were the characteristics that shaped their resentments and their behavior in the thirties.

These are not easy distinctions to identify or measure; and often they were subjective rather than objective. Memoir literature is particularly helpful in providing illustrations of how they operated. Khrushchev; for example, in recounting his advancement in the Communist Party in the 1920s, frequently uses the term "we" to distinguish those like himself in background and experience -- and it is clear that "we" identified strongly with Stalin. "At the time of the Fifteenth Party Congress we had no doubt in our minds that Stalin and his supporters were right, and that the opposition was wrong... We realized that a merciless struggle against the opposition was unavoidable".50 Khrushchev is more specific in pinpointing who "we" were when he describes the political line-up at the Stalin Industrial Academy in 1929:

There was a group of us at the academy who stood for the General Line and who opposed the rightists: Rykov, Bukharin, and Uglanov, the Zinovievites; the Trotskyites, and the right-left bloc of Syrtsov and Lominadze. I don't even remember exactly what the differences were between Bukharin and Rykov on the one hand and Syrtsov and Lominadze on the other. Rightists, oppositionists, right-leftists, deviationists -- these people were all moving in basically the same political direction; and our group was against them. We all came fram the South -- fram the Donbass, from Dniepropetrovsk; and from Kharkov. Furthermore, we had all joined the Party after the Revolution. When someone's candidacy to a post in the academy organization was proposed at a meeting he had to go to the podium and say where he was from and when he had joined the Party. This made it easy for the old Guard in the Party cell to recognize and vote down anyone who was likely to oppose them. 51

It is a telling point that what stuck in Khrushchev's memory decades later was not the ideological camplexities of the opposition struggles of the late twenties; which he treats very casually indeed; but the resentment "our group" 
felt against "these people." Khrushchev's account suggests strongly that the cultural and social antagonism between provincial; poorly educated newcomers like himself and the more sophisticated and solidly entrenched old Guard considerably exacerbated; and possibly even transcended; their political differences. 52

A very different sense of self-identification is voiced in the memoirs of Eugenia Ginzburg; one of the victims of the Great Purge. Ginzburg was a loyal Party member; but she belonged to an entirely different cultural realm from Khrushchev. A journalist and teacher; with reams of Russian poetry tucked away in her head; the wife of an important provincial Party official; she was an integral part of the entrenched elite. This is her reaction upon finding herself in a prison-camp hospital at one point in her siberian odyssey:

I had seen no men of this sort; our sort - the intellectuals, the country's former establishment - since transit camp... The men here were like us. Here was Nathan Steinberger, a Geman Communist from Berlin. Next to him was Trushnov, a professor of language and literature from somewhere along the Volga; and over there by the window lay Arutyunyan; a former civil engineer from Leningrad... By some sixth sense they immediately divined that I was one of them and rewarded me with warm, friendly, interested glances. They were just as interesting to me. These were the people I used to know in my former life. 53

A certain amount of generational difference is to be expected between the old elite and the new; and sentiments similar to Ginzburg's can be found in the memoirs of older intellectuals who clearly belonged to the pre-revolutionary intelligentsia.54 The gap was only in part a generational one; however Ginzburg was in fact younger than Khrushchev. It was a more fundamental difference in cultural and educational experience; a product of social background and the type and degree of education. 55

This cultural gap sheds light not only on the social change which the Ezhovshchina had the effect of completing and consolidating; but on other aspects of the Great Purge as well. The viciousness of the charges levelled 
against the victims of the purge; and the apparent willingness of much of the Russian public to accept them, seems evidence of a considerable social and cultural distance between the elite that was decimated by the Ezhovshchina and the rest of Soviet society. Several recent scholars have found continuities; or at least parallels; between the "cultural revolution" of the late twenties and the Ezhovshchina; both of which were marked by a certain streak of "populism": in each case; the authorities at the center were able to draw on a degree of support from below when it came to intelligentsia-baiting and attacks on local "bosses."56 The new elite - and much of the soviet public at large; which shared the new men's cultural background - could accept and even approve of the Great Purge; both because in many cases they were its direct beneficiaries and because most of the victims were so alien to them that the accusations against them seemed not implausible.

To be sure; same of the new men were themselves swept away in the Ezhovshchina. But the characteristics of the newcomers prepared them to accept the high risks; as well as the potential rewards; of service under Stalin. Khrushchev; for example; felt that he owed his survival in part to his good relations with Stalin's wife; Nadezhda Allilueva; a fellow-student at the Industrial Academy; and terms this his "lucky lottery ticket." He adds that "we" always followed the rule that if you weren't told something you didn't ask about it; for the less you knew; the better. 57 Hard work; wariness; and a good bit of luck were essential to success - but if the axe fell after all; well; life was harsh; wasn't it? General Alexander Gorbatov provides a good illustration of the new elite's resilience. Gorbatov came from a large; poor peasant family; fought in World War I and the Civil War; joined the Bolshevik Party in 1919; and rose successfully through the military ranks. As he says in his memoirs; in the tsarist anmy there was a saying that 
"it's a bad soldier who doesn't hope to become a general;" but in the Red Army that hope became a real possibility. 58 In 1938, however, caught up in the military purge; he was imprisoned, sent to forced labor in Kolyma - and then reinstated in the army just before the war began. Despite the humiliations and brutality he had endured, he resumed his career; served faithfully and successfully, and was one of the generals in command of the Russian forces that captured Berlin. More than just ambition or patriotism; a peasant toughness and acceptance of life's caprices seem to underlie such stories; enabling both the new elite and the system itself to survive under Stalin.

If one does choose to characterize the displacement of the entrenched Soviet Establishment by the new Stalinist elite as the rise of a "new class," the term should not be taken in a Marxist or Trotskyist sense. To conclude our discussion of the social change that occurred in the thirties, it is useful to turn back for a moment to the man who was actually the father of the modern concept of the "new class," Jan Wacław Machajski. Born in Russian Poland in 1866; Machajski became active in the Russian revolutionary movement and at the turn of the century began to develop his distinctive views; which were known as Makhaevshchina; or Makhaevism; and had fairly widespread currency in the years before the Revolution. Among those familiar with Makhaevism, in fact, was Trotsky, who had read some of Machajski's writings during an early stint of Siberian exile. It cannot be determined whether; or to what extent; Trotsky drew on Machajski's ideas in formulating his notion of Stalinism as "bureaucratic degeneration." (Machajski himself died in Moscow in 1926.) It was Machajski; however, who first developed the concept of the "new class" and gave it a content that makes it highly pertinent to the Stalin period. 59 
Machajski saw modern class divisions not in strictly socio-economic terms but more fundamentally in cultural and educational terms. The primary division in capitalist society was not; as the Marxists maintained; the one between the capitalists and the proletarians; but the one that divided all of "educated society" and the manual workers. Those who "owned" the technical; professional; and managerial knowledge essential for running a modern industrial society (the "intellectual workers;" or "brain workers;" as Machajski termed them) belonged to the privileged; exploiting part of society; while those who lacked such education and the possibility of acquiring it were excluded from power and privilege and condemned to lifelong physical labor. A socialist revolution would by no means overcome this division; Machajski contended; it would perpetuate itself even after the overthrow of capitalism and the socialization of the means of production. Having used the labor movement to ride to power the "intellectual workers;" led by the socialists; would merely replace the capitalists; the property-owning wing of educated society, as the new ruling class and the new exploiters of the manual workers. Their monopoly of the specialized knowledge essential to economic production would remain intact; and their privileged position would now be more secure than when they had had to serve the capitalists. Machajski therefore called for a second revolution to follow the socialist revolution much as Trotsky was to call for a new proletarian revolution against the Stalinist bureaucracy. The manual workers must force the new rulers to equalize wages; which in turn would produce what Machajski called the "socialization of knowledge" : educational equality for the children of manual workers and the elimination of the educational gap that conderned the workers to an inferior position. 
To a remarkable degree; what occurred in the 1930s followed Machajski's prescription for a "second revolution." The distinction between "educated society" (which could include anyone who sat behind a desk; whether truly educated or not) and manual workers (or those who identified with them) was the crucial distinction that surfaced; with Stalin's encouragement, from the "cultural revolution" through the Great Purge; this was a Makhaevist, not a Marxist, distinction. Fram the Shakhty Trial to the Ezhovshchina; the postrevolutionary Soviet Establishment was under attack: Old Bolsheviks (but not just Old Bolsheviks); local Party bosses; the "bourgeois" professional, managerial; and technical elite, were objects of a hostility comparable to that previously directed against the property-owning classes. Fram the point of view of ordinary workers and peasants; this Establishment could easily seem a mere extension of the old propertied classes, "bourgeois" by status, education, and culture, if not in strictly socio-economic terms. 60

Meanwhile; the educational crash program that accompanied the First FiveYear Plan began to create a new political; technical, and managerial elite drawn from the truly plebeian ranks of Soviet society. With the Great Purge the displacement of the old Establishment ("old" only in terms of a decade, to be sure, but even a decade can seem significant in a revolutionary age) by the new elite reached its culmination, consolidating Stalin's political power but at the same time completing a social and cultural transformation that would long outlive its sponsor. The end result; of course; was not the kind of egalitarian society Machajski had had in mind when he called for the "socialization of knowledge." Instead; a new privileged stratum arose - but one that was in many ways more accessible and more "democratic" in its origins than the previous one. 
Fram this perspective; Stalinism must be seen as a logical outcame of the historical course Russia had been following since 1917, the final phase of a bitter rebellion against property and privilege which finally brought into positions of leadership representatives of precisely the classes in whose name the October Revolution had been carried out. It was not simply a deviation or degeneration from some kind of norm; either psychological; political; or ideological; and to the extent that it was related to Russia's "modernization" the relationship was rooted in social and cultural conditions specific to Russia. With the rise of a new elite of plebeian origins under Stalin's auspices; the 1930s marked a fulfillment of the "democratic" principles of the October Revolution - a fulfillment; be it stressed; not the fulfillment; for had the times and the leaders been different; the costs; timing; and methods might well have been different also. 61 social mobility alone; after all; cannot account for such developments as the terror of the Ezhovshchina; and here some aspects of traditional historiographical approaches to the question of Stalinism retain their usefulness.

Same of the specific features of Stalinist politics and culture which have long seemed aberrant; however; can be explained by the rise of the new elite; and the rise of that new elite marks the great historical significance of Stalinism as a whole. In a process culminating in the Great Purge; workerpeasant Russia; having rid itself of the old propertied and ruling classes; now turned against the new post-revolutionary elite, many of whose members were of middle-class origin and "bourgeois" in their education and cultural orientation. The latter were naturally bewildered at their cruel fate; and their bewilderment generated some of the theories of Stalin's rule that have long marked the historiography of the period. Their fate becomes less bewildering, though no less cruel, as our historical perspective on it 
broadens and deepens. If the political; social; and economic structures that took shape in the thirties have survived largely intact into the eighties without pervasive terror or the cult of Stalin; it is because those structures had deep social roots which Stalin's death did nothing to alter. And if what we have come to call the "new class" in the Soviet Union has demonstrated such staying power; it is because its members are not just the "heirs of Stalin" but the heirs of 1917 and of Russian history. 


\section{FOOTNOTES}

1. Robert Conquest comes up with an estimate of three million dead and nine million held in prisons and camps by the end of 1938. The Great Terror: Stalin's Purge of the Thirties; revised ed. (New York: Collier Books; 1973), pp. 708-09. According to Roy Medvedev; "In 1936-39; on the most cautious estimates, four to five million people were subjected to repression for political reasons." Let History Judge: The Origins and Consequences of Stalinism, trans. by Colleen Taylor; ed. by David Joravsky and Georges Haupt (New York: Knopf; 1971); p. 239. At the lower end of the scale, Jerry Hough regards "a figure in the low hundreds of thousands" as the most probable number of deaths in the Great Purge. Jerry F. Hough and Merle Fainsod; How the Soviet Union is Governed (Cambridge; Mass.: Harvard University Press, 1979); p. 177. Conquest (chap. 10 and Appendix A) provides the most extensive discussion of attempts to estimate the number of victims. It is particularly revealing of the widely divergent dates; categories of victims; and types of sources that go into the making of such estimates; as well as the amount of inspired guesswork involved.

2. For a critique of the standard sources on the Great Purge; see John Arch Getty; "The 'Great Purges' Reconsidered: The Soviet Camunist Party; 1933-1939;" (Ph.D. Dissertation; Boston College; 1979); pp. 24-48. Both Medvedev's Let.'History.Judge and Alexander Solzhenitsyn's The'Gulag Archipelago, 1918-1956: An Experiment in Literary Investigation; 3 vols., trans. by Thomas P. Whitney (vols. 1-2) and Harry Willetts (vol. 3) (New York: Harper \& Row; 1973-78); make extensive use of umpublished letters and memoirs on the Great Purge; most of which would never be available to a Western researcher. On the other hand; same of the limitations inherent in the use of unpublished personal accounts are reflected all too clearly in Anton Antonov- 
Ovseyenko's The Time of Stalin: Portrait of a Tyranny; trans. by George Saunders (New York: Harper \& Row, 1980), which seems to have assembled all the nasty rumors and gossip available on the subject of Stalin. See the detailed review by M. Dovner, "Lubok vmesto istorii," Pamiat': istoricheskii sbornik, vyp. IV (Paris: YMCA-Press, 1981), pp. 442-55, which points out the numerous inconsistencies and unverified and improbable stories the book contains.

3. Examples are Getty's "The 'Great Purges' Reconsidered," based on extensive use and reappraisal of the Smolensk Archive, and two literary studies which have found new meaning in the Stalinist novel: Vera Dunham, In Stalin's Time: Middleclass Values in Soviet Fiction (Cambridge University Press, 1976); and Katerina Clark, The Soviet Novel: History as Ritual (Chicago: University of Chicago Press, 1981).

4. A good example of a fresh interpretation of such material is Robert Tucker's re-reading of the Bukharin show-trial. See his Introduction to Robert C. Tucker and Stephen F. Cohen, eds., The Great Purge Trial (New York: Grosset and Dunlap; 1965). Also worth noting is Robert H. McNeal's admonition to study more closely the large body of Party decisions relating to the purge years. See his "The Decisions of the CPSU and the Great Purge," Soviet Studies, 22, 2 (October 1971), 177-85; also; Robert H. McNeal, gen. ed., Resolutions and Decisions of the Communist Party of the Soviet Union, 4 vols. (Toronto: University of Toronto Press, 1974). The same might be said of Stalin's own writings and speeches, which MaNeal has also helped to make more accessible. See Robert H. McNeal, ed., I. V. Stalin, Works, 1934-1953, 3 vols. (Stanford: Hoover Institution, 1967), a supplement to the 13-volume Soviet edition.

5. Boris I. Nicolaevsky, ed., The Crimes of the Stalin Era (New York: The New Leader, 1962), p. S34. 
6. Svetlana Alliluyeva; Twenty Letters to a Friend; trans. by Priscilla Johnson MaMillan (New York: Harper \& Row; 1967); p. 8 and passim; AntonovOvseyenko; The Time of Stalin; pp. $51 ; 252 ; 308$.

7. These works differ from traditional political biographies such as Bertram D. Wolfe's Three Who Made a Revolution: A Biographical History; revised ed. (New York: Dell; 1964); or Adam B. Ulam's Stalin: The Man and His Era (New York: Viking Press; 1973); in that the latter; while offering considerable psychological insight into their subject; do not explicitly make use of formal theory.

8. Robert C. Tucker; "The Dictator and Totalitarianism;" in The Soviet Political Mind: Stalinism and Post-Stalin-Change; revised ed. (New York: Norton; 1971); pp. 20-46; Philip Pamper; "Nečaev; Lenin; and Stalin: The Psychology of Leadership;" Jahrbücher für Geschitchte Osteuropas; Neue Folge; Band 26 (1978); Heft 1; pp. 11-30; and the strident and poorly informed essay by Gustav Bychowski; "Joseph V. Stalin: Paranoia and the Dictatorship of the Proletariat;" in Benjamin B. Wolman; ed.; The Psychological Interpretation of History (New York: Basic Books; 1971); pp. 115-49. On the other hand; a recent survey of psychohistorical literature concludes that the answer to the question; was Stalin paranoid?; "must be a qualified no." Salvatore Prisco III; An Introduction to Psychohistory: Theories and Case Studies (Lanham; MD: University Press of America; 1980); p. 144.

9. Robert C. Tucker; Stalin as Revolutionary; 1879-1929: A Study in Fistory and Personality (New York: Norton; 1973).

10. Alliluyeva; Twenty Letters to a Friend; and Only One Year; trans. by Paul Chavchavadze (New York: Harper \& Row; 1969); Milovan Djilas; Conversations with Stalin; trans. by Michael B. Petrovich (New York: Harcourt; Brace \& World; 1962). For an evaluation of the clues to Stalin's personality 
contained in his daughter's writings; see Robert C. Tucker; "Svetlana Alliluyeva as Witness of Stalin," Slavic Review, 27; 2 (June 1968); 296-312.

11. A cautionary example of those difficulties is the effort that has gone into analyzing a pencilled doodle that Stalin made during the Yalta Conference. See Charles S. Clark; "The Stalin Doodles," Manuscripts, 35, 2 (Spring 1983); 101-12. I am grateful to Stephen Nonack of the Boston Athenaeum for bringing this item to my attention. For an examination of the genre of psychobiography and some of its problems; see William McKinley Runyan, Iife Histories and Psychobiography: Explorations in Theory and Method (New York: Oxford University Press, 1982); chap. 10.

12 Carl J. Friedrich and Zbigniew K. Brzezinski; Totalitarian Dictatorship and Autocracy, 2nd ed. (Cambridge Mass.: Harvard University Press, 1965); Merle Fainsod, Smolensk under Soviet Rule (Cambridge; Mass.: Harvard University Press; 1958); and How Russia is Ruled, revised ed. (Cambridge, Mass.: Harvard University Press, 1963). Roger Pethybridge's The Social Prelude to Stalinism (London: Macmillan; 1974) is a more recent work which also adopts the framework of totalitarianism but with emphasis on its sociological rather than merely political or ideological roots.

13. Zbigniew K. Brzezinski; The Permanent Purge: Politics in Soviet Totalitarianism (Cambridge; Mass.: Harvard University Press, 1956).

14. The leading exponent of this approach is Jerry Hough; who develops the concept of "institutional pluralism" to characterize the Soviet political system. Jerry F. Hough; The soviet Union and social Science Theory (Cambridge; Mass.: Harvard University Press; 1977). Although he applies this model principally to the post-Stalin Soviet Union, he suggests that to same degree it may be applicable to the Stalin period as well. Ibid.; p. 12; Jerry F. Hough; "The Cultural Revolution and Western Understanding of the Soviet 
System;" in Sheila Fitzpatrick; ed.; Cultural Revolution in Russia;-1928-1931 (Blocmington: Indiana University Press; 1978). pp. 250-51. J. Arch Getty paints a picture of the Communist Party in the late twenties and early thirties as a distinctly unkempt organization which scarcely knew who its members were; and whose central institutions in Moscow were often able to exert only weak and ineffectual control over local Party officials. Getty, "The 'Great Purges' Reconsidered;" esp. chap. 2; and "Party and Purge in Smolensk: 1933-1937;" with discussion by Robert C. Tucker and Niels Erik Rosenfeldt; Slavic Review; 42; 1 (Spring 1983); 60-96.

15. See; for example; David E. Powell; "In Pursuit of Interest Groups in the USSR;" Soviet Union; 6; 1 (1979); 99-124; and replies by Jerry F. Hough and Peter H. Solomon; Jr., ibid., 8, 1 (1981), 103-18.

16. Alexander Solzhenitsyn et al., From Under the Rubble, trans. by A. M. Brock et al. (Boston: Little, Brown, 1975).

17. Nadezhda Mandelstam, Hope against Hope: A Memoir, trans. by Max Hayward (New York: Atheneum; 1970), esp. chaps. 36-37, and Hope Abandoned, trans. by Max Hayward (New York: Atheneum, 1974).

18. See; for example; Conquest; The Great Terror; pp. 19-25.

19. The sharp demarcation between Lenin and Stalin is somewhat modified but not fundamentally questioned in his more recent on Stalin and Stalinism; trans. by Ellen de Kadt (Oxford: Oxford University Press; 1979).

20, Leon Trotsky; The Revolution Betrayed: What is the soviet Union and Where Is It Going?; trans. by Max Eastman (New York: Pathfinder Press; 1972; first ed.: 1937); Stalin: An Appraisal of the Man and His Influence (New York: Stein and Day; 1967; first pub. 1941). On Trotsky's theory and its subsequent development by his followers; see Robert H. MaNeal; "Trotskyist Interpretations of Stalinism," in Robert C. Tucker, ed., Stalinism: Essays in 
Historical Interpretation (New York: Norton; 1977); pp. 30-52; and Baruch Knei-Paz; The Social and Political Thought of Leon Trotsky (Oxford: Clarendon Press; 1978); chap. 10. McNeal's conclusion is that "In a sense Trotsky struggled to avoid making a Marxist analysis of Stalinism" (p. 51).

21. Stephen F. Cohen, Bukharin and the Bolshevik Revolution: A Political Biography; 1888-1938 (New York: Knopf; 1973); M. Lewin; Russian Peasants and Soviet Power: A Study of Collectivization, trans. by Irene Nove (New York: Norton, 1975).

22. Isaac Deutscher; Stalin: A Political Biography; 2nd ed. (Oxford: Oxford University Press; 1966); pp. 565-66, 568; 569. On the evolution of Deutscher's interpretation; see McNeal; "Trotskyist Interpretations;" pp. 4851.

23. For example: "The objective basis for the Stalin phenomenon does not in any way exist in contemporary France; for example, where the level of the productive forces is already high... it was a phenomenon restricted in terms of time and place; and not a historical necessity universally true of socialism, whether past; present or future." The Stalin Phenomenon; trans. by Peter Latham (London: Lawrence and Wishart; 1976); p. 60.

24. To cite two examples; see Charles K. Wilber; The Soviet Model and Underdeveloped Countries (Chapel Hill: University of North Carolina Press; 1969); and the essays by Alex Inkeles in his Social Change in Soviet Russia (Cambridge; Mass.: Harvard University Press, 1968). For same pertinent criticism of the idea that Stalinism might serve as a model for underdeveloped countries today; see Robert C. Tucker's remarks in G. R. Urban; ed.; Stalinism: Its Impact on Russia and the World (New York: St. Martin's Press, 1982); pp. 168-77. 
25. As one scholar has put it; "Precisely because Stalinism joined a radical transformation of the economic; political; and social bases of soviet society to a system of values and a pattern of authority relations with powerful traditionalist and authoritarian components; it gave a very special character to Soviet patterns of modernization." Gail Warshovsky Lapidus, "Educational Strategies and Cultural Revolution: The Politics of Soviet Development," in Fitzpatrick, ed., Cultural Revolution in Russia, p. 103.

26. Theodore H. Von Laue, Why Lenin? Why Stalin? A Reappraisal of the Russian Revolution; 1900-1930; 2nd ed. (Philadelphia: Lippincott; 1971), and "Stalin Among the Moral and Political Imperatives; or How to Judge Stalin?" Soviet Union; 8; 1 (1981); 1-17.

27. As late as 1978, Sheila Fitzpatrick could write that "Stalin's Russia is still almost uncharted territory for the historian." Cultural Revolution in Russia, p. 7. Katerina Clark makes a similar point in remarking that in Western scholarship the subject of Soviet Socialist Realism "can be discussed, but preferably only in tones of outrage, bemusement, derision; or elegy." The Soviet Novel, p. ix.

28. Nicolaevsky; ed.; The Crimes of the Stalin Era; p. S26.

29. For example; Fainsod, Smolensk under Soviet Rule; pp. 451-54.

30. Robert Eugene Johnson's Peasant and Proletarian: The Working Class of Moscow in the Late Nineteenth Century (New Brunswick: Rutgers University Press, 1979) is a recent reminder of the extent to which Russian industrial workers were rooted in peasant culture. See also Diane Koenker, Moscow Workers and the 1917 Revolution (Princeton; NJ: Princeton University Press, 1981); chaps. 1-2. Moshe Lewin makes a similar point for the period of the First Five-Year Plan in his "Society; State; and Ideology during the First Five-Year Plan;" in Fitzpatrick, ed., Cultural Revolution in Russia, pp. 4l- 
77. Pethybridge's Social Prelude"to-Stalinism deals extensively with the impact of Russian peasant tradition on the rise of Stalinism; and some older works long ago pointed to the peasant roots of the new elite. The figure of Gletkin in Arthur Koestler's Darkness at Noon, published in 1941, comes to mind, and Nicholas Vakar's The Taproot of Soviet Society (New York: Harper and Brothers, 1962) is an essay devoted to the subject.

31. Kendall E. Bailes, Technology and Society under Lenin and Stalin: Origins of the Soviet Technical Intelligentsia, 1917-1941 (Princeton, NJ: Princeton University Press; 1978); chaps. 3-6. Sheila Fitzpatrick, Education and Social Mobility in the Soviet Union, 1921-1934 (Cambridge: Cambridge University Press; 1979); chap. 6; and "Stalin and the Making of a New Elite, 1928-1939," Slavic Review, 38, 3 (September 1979); 377-93. On various aspects of the "cultural revolution," see the articles in Fitzpatrick, ed., Cultural Revolution in Russia.

32. Fitzpatrick; Education and Social Mobility; pp. 186-89; Bailes; Technology and Society; pp. 188-201. "To Stalin; all the reforms of the thirties, from expansion to educational facilities to Stakhanovism to the abolition of wage differentials were designed to create the red specialists. To him, these red technicians were necessary for rapid economic growth without having to depend on the 'class eneny' specialists of the bourgeoisie." Getty, "The 'Great Purges' Reconsidered," p. 498.

33. Khrushchev Remembers; trans, and ed. by Strobe Talbott (Boston: Little, Brown; 1970); pp. 34-35; Petro G. Grigorenko, Memoirs; trans. by Thamas P. Whitney (New York: Norton; 1982), pp. 30-31. For additional examples, see Bailes; Technology and Society, pp. 198-200; and Fitzpatrick; "Stalin and the Making of a New Elite," pp. 385-86. 
34. The Party "Thousands;" however; special levies of Party members recruited for higher technical education in the years 1928-31; the great majority of whan were workers; were called upon to help enforce collectivization in the countryside. Bailes; Technology and Society; pp. 198, 255,259 .

35. Grigorenko; Memoirs; p. 22.

36. Grigorenko; for example, a witness to the devastating effects of collectivization on the countryside; writes: "I blamed all this on the peasantry's lack of conscientiousness and undertook a one-man struggle against the people's indifference." He sums up his attitude in the following words: "In 1930-31 the Soviet Union had a totally ruined agricultural system and a disorganized transport system. Yet people like me continued to be hypnotized by the old ideals and the new construction projects." Ibid., pp. 39, 40. It should also be remembered that Khrushchev, in the late fifties and early sixties, instigated one of the most virulent anti-religious campaigns of Soviet history - religion being something that he seems to have identified with the peasant backwardness of his childhood. See Khrushchev Remembers; p. 22.

37. Ibid.; pp. $30 ; 34$.

38. "As Stalin was speaking [this is in 1930] I thought to myself; 'Here is a man who knows how to direct our minds and our energies toward the priority goals of industrializing our country and assuring the impregnability of our Homeland's borders against the capitalist world; the well-being of the people is obviously in firm hands!'" Ibid.; p. 37. Grigorenko testifies to the ready appeal of Stalin's argument for "socialism in one country." Memoirs, p. 25. 
39. Although it took place at a much later date; Khrushchev's outburst against abstract art during his celebrated visit to the Manezh Gallery in 1961 provides a reflection of his cultural tastes and of his suspicion of art that he could not understand or appreciate. Priscilla Johnson and Leopold Labedz, eds.; Khrushchev and the Arts: The Politics of Soviet Culture, 1962-1964 (Cambridge; Mass.: M.I.T. Press; 1965); pp. 101-05. The classic work on the cultural changes of the thirties is Nicholas S. Timasheff, The Great Retreat: The Growth and Decline of Communism in Russia (New York: Dutton; 1946). See also Fitzpatrick; Education and Social Mobility; pp. 249-54.

40. Clark; The- Soviet Novel; chaps. 2-8; and "Little Heroes and Big Deeds: Literature Responds to the First Five-Year Plan," in Fitzpatrick," ed., Cultural Revolution in Russia; pp. 189-206. See also her article "Utopian Anthropology as a context for Stalinist Literature;" in Tucker, ed., Stalinism, pp. 180-98. Dumham, In Stalin's Time, chap. 3. Aleksandr I. Solzhenitsyn; The First Circle; trans. by Thomas P. Whitney (New York: Harper \& Row, 1968); chap. 56.

41. Clark; The Soviet Novel; pp. 201-03. It is tempting to see the final stage of this life-cycle reflected in a one-page story which appeared in the Leningrad literary journal Avrora in December of 1981 . It described a great writer who stubbornly refuses to die and assume the rightful place of a classic: "Any man who had written so many books would long since have been lying in the grave. But this one is truly superhuman [nechelovek]! He lives and has no intention of dying, to the amazement of one and all. Most people think that he died a long time ago; so great is the admiration of this talent." Appearing on p. 75 of the issue dedicated to the seventy-fifth birthday of Leonid Brezhnev; it was considered by many to be a satire on the 
long-ailing leader. Viktor Goliavkin; "Iubileinaia rech';" Avrora (December 1981); p. 75. See Newsweek; November 22, 1982; p. 39

42. Quoted in Fitzpatrick, "Stalin and the Making of a New Elite," p. 399. See also Fitzpatrick; Education and Social Mobility; pp. 239-49; and "Stalin and the Making of a New Elite;" pp. 393-402; Getty; "The 'Great Purges' Reconsidered;" pp. 489-501. Even Soviet publications have called attention to the large-scale promotion of new men as a result of the Great Purge. In 1966; Voprosy istorii made the following statement: "In 1937-38 Soviet industry suffered a heavy blow as a result of mass repressions. The loss thus inflicted was difficult to make good. A large number of young engineers who had graduated from technical college as late as 1933 or 1934 became directors of enterprises; and many gifted organizers of production arose from their ranks as the new commanders gradually gained experience." Quoted in Boris Levytsky, ed.; The Stalinist Terror in the Thirties: Documentation from the Soviet Press (Stanford: Hoover Institution; 1974), p. 421 .

43. This seems to be Fitzpatrick's cautious, but plausible; conclusion in "Stalin and the Making of a New' Elite," p. 401.

44. Getty; "The 'Great Purges' Reconsidered;" pp. 532-33.

45. Fitzpatrick; "Stalin and the Making of a New Elite;" pp. 385, 397.

46. Merle Fainsod; for example, concluded Smolensk under Soviet Rule with an examination of a "new class" of beneficiaries of Stalinism (pp. 451-54). Sheila Fitzpatrick also uses the term in her Introduction to Cultural Revolution in Russia; p. 7; and Education and Social Mobility; p. 249-54.

47. Trotsky, The Revolution Betrayed; pp. 86-94. Marc Ferro also sees the origins of Stalinism in "bureaucratization;" but as early as 1917 and in more specific social terms. In the course of 1917 he finds the various 
popular institutions generated by the Revolution; the soviets; factory and district committees; Red Guards; etc.; undergoing a process of bureaucratization; with new plebeian elements joining former tsarist officials; intelligentsia; and old Guard Bolsheviks to form the apparatchiki of the new Soviet state. The Stalin era represented the rise to damination of the plebeians; who were predominantly of peasant origin; at the expense of the other elements. October 1917: A Social History of the Russian Revolution; trans. by Norman Stone (London: Routledge \& Kegan Paul; 1980); pp. 196-202; 274-77.

48. MaNeal; "Trotskyist Interpretations of Stalinism;" pp. 36-48; KneiPaz; The Social and Political Thought of Leon Trotsky; pp. 410-41. See also Milovan Djilas; The New Class: An Analysis of the Conmunist System (New York: Praeger; 1957).

49. Trotsky; The Revolution Betrayed; pp. 249-50.

50. Khrushchev Remembers; p. 30.

51. Ibid.; p. 39.

52. Is Khrushchev's reference to common geographical origin ("We all came fram the south") possibly an echo of the zemliachestvo; the regional network through which migrant peasant-workers often were recruited by factories before the Revolution -- and thus another reminder of the impact of peasant culture on "the Khrushchevs"? On the zemliachestvo; see Johnson; Peasant and Proletarian; chap. 4.

53. Eugenia Ginzburg; Within the Whirlwind; trans. by Ian Boland (New York: Harcourt Brace Jovanovich; 1981); p. 112. This is the second volume of Ginzburg's memoirs; the first being Journey into the Whirlwind (New York: Harcourt; Brace \& World; 1967). 
54. Both Ivanov-Razummik and Nadezhda Mandel'shtam; for exarmple; camment on the precipitous decline of literary knowledge on the part of secret police interrogators as the thirties progressed -- in a Russian context; probably as good an index of cultural stratification as any. The Memoirs of IvanovRazumik; trans. by P. S. Squire (London: Oxford University Press, 1965), pp. 139-50; Mandelstam; Hope against Hope; p. 79.

55. Getty compared the 1934 and 1939 Central committees and found that the great majority of the 1934 Central Camittee had been educated before the Revolution; while most of the 1939 Central Committee members had been educated in the twenties or even the thirties. "The 'Great Purges' Reconsidered," pp. 512-13.

56. Ibid.; pp. 165-204, 456-57; 499-500; Hough; "The Cultural Revolution and Western Understanding of the Soviet System," pp. 245-47; Fitzpatrick, "Stalin and the Making of a New Elite," passim.

57. Khrushchev Remembers; pp. 44; 79.

58. A. V. Gorbatov, "Gody $i$ voiny," Novyi mir (April 1964), p. 100. Gorbatov's memoirs were serialized in the March, April, and May, 1964 issues of Novyi mir. An abridged English translation is A. V. Gorbatov; Years off My Life, trans. by Gordon Clough and Anthony Cash (London: Constable, 1964).

59. For summaries of Machajski's doctrines see Paul Avrich; "What Is 'Makhaevism'?" Soviet Studies, 17, 1 (July 1965), 66-75; Marshall S. Shatz, "Jan Waclaw Machajski: The 'Conspiracy' of the Intellectuals," Survey, No. 62 (January 1967); pp. 45-57; and "The Makhaevists and the Russian Revolutionary Movement," International Review of Social History, 15; 2 (1970), 235-65; Anthony D'Agostino; "Intelligentsia Socialism and the 'Workers' Revolution': The Views of J. W. Machajski," International Review of Social History; 14; 1 (1969); 54-89. For Trotsky's comments on Machajski see L. Trotskii, 
"Vospominanila o moi pervoi sibirskoi ssylke," Katorga i ssylka, No. 5 (1923), pp. 91-95, and Leon Trotsky, My Life: An Attempt at an Autobiography (New York: Scribner, 1930), pp. 129, 143.

60. Marc Ferro, characterizing this process, includes a particularly apposite phrase from Gorky: "One function of the purges and show-trials was to eliminate the former privileged groups to wham even the 'old style' Bolsheviks had belonged despite their being, historically, in the 'vanguard'. The $r$ ise of popular elements could quite easily be adapted to the elimination, both at the top and at lower levels, of these formerly privileged elements, 'these men with their knowledge, all these swine', as Gorky said." October 1917, p. 202. 61. As Sheila Fitzpatrick neatly puts it, and with appropriate emphasis, the Revolution turned out to be a matter of "terror, progress and upward mobility." The Russian Revolution (Oxford: Oxford University Press, 1982), p. 8. 


\section{To order, contact:}

The Carl Beck Papers

Center for Russian and East European Studies

4G-12 Forbes Quadrangle

Box 305

University of Pittsburgh

Pittsburgh, PA 15260

Tel: 412-648-9881; Fax: 412-648-2199;

Email: CREES@vms.cis.pitt.edu 